TEME, г. XLII, бр. 3, јул - септембар 2018, стр. 979-997

Прегледни рад

DOI: $10.22190 /$ TEME1803979M

Примљено: 5. 8. 2017.

UDK 327.2:355.013

Ревидирана верзија: 29. 12. 2017.

Одобрено за штампу: 9. 1. 2018.

\title{
ЕВАЛУАЦИЈА ЕКОНОМСКОГ ЕКСПАНЗИОНИЗМА КРОЗ ПРИЗМУ ВИШЕСТРУКЕ ДИСЦИПЛИНАРНОСТИ
}

\author{
Славица Манић \\ Универзитет у Београду, Економски факултет, Београд, Србија \\ slavica@ekof.bg.ac.rs
}

\begin{abstract}
Апстракт
О економији се говори и пише више него што се зна и разуме. Она у тој мери прожима наше животе да тврдња „сви смо ми помало економисти” представља смислен, иако не нужно истинит, исказ (осим, евентуално, у врло уском поимању економије као умећа). Ипак, економија би, као и свака друга наука, била излишна „кад би се облик и суштина ствари непосредно подударали”. Иако економисти не оспоравају преплитање науке и умећа, већина ће рећи да се економија етаблирала као научна дисциплина са особеним подручјем истраживања. Такође, знатан број економиста ће подржати тежње о трансферу, те спорадичној или организованој размени идеја, концепата и метода између различитих подручја истраживања. Следствено томе, економисти ће у начелу прихватити експанзионизам као позитиван тренд који економији и другим дисциплинама доноси само корист. Циљ овог текста је да, кроз преглед релевантне литературе, прикаже покушај економије да оствари своје експанзионистичке амбиције и афирмише се као универзална наука, ослонивши се на погрешно тумачење, а можда и злоупотребу идеје вишеструке дисциплинарности.
\end{abstract}

Кључне речи: експанзионизам, економски империјализам, интердисциплинарност, мултидисциплинарност, вишеструка дисциплинарност.

\section{EVALUATION OF ECONOMIC EXPANSIONISM THROUGH THE PRISM OF MULTIPLE DISCIPLINARITY}

\begin{abstract}
Economics has been uttered, spoken and written about more than it is studied and/or understood. It impregnates our lives to such extent that the claim "now and then we're all economists" represents a meaningful, though not necessarily true statement (except, possibly, in a very narrow sense when it is grasped as a skill). However, economics, like any other science, would be superfluous "if the form and essence directly coincide." Although economists do not dispute the interweaving of science and skills, most of them
\end{abstract}


will say that economics has established itself as a scientific discipline with particular field of research. Also, a number of economists will support transfer and exchange of ideas, concepts and methods among different research fields. Consequently, economists will in principle accept expansionism as a positive trend bringing to economics and other disciplines nothing but benefits. The aim of this paper is to indicate (through a review of relevant literature) economics' attempt to realize its expansionist ambitions in order to establish itself as a universal science (general philosophy of the society) by misinterpreting or even abusing the idea of multiple disciplinarity.

Key words: expansionism, economics imperialism, interdisciplinarity, multidisciplinarity, multiple disciplinarity.

\section{УВОДНА РАЗМАТРАњА}

У двадесетом веку кулминирала је растућа фрагментираност научних дисциплина (у којима, по правилу, доминира неки облик редукционистичког приступа). И поред дуготрајног инклинирања константном сегментирању, науке нису биле омеђене некаквим непробојним оградама, те су трансфер концепата и метода, односно размена идеја, текли у почетку спорадично, а касније на утемељен и организован начин, што је резултирало појавом нових наука, али и разноликих „хибрида” - изведених дисциплина (Savoiu, 2014). Овакви спојеви најчешће су се дешавали у областима које су природно конвергирале једне другима (физичка хемија, биофизика, биохемиjа...) и представљале су оличење оних видова међудисциплинарне сарадње који служе за пример другима. А будући да смо у друштвеном, политичком и економском животу деценијама уназад сведоци тренда глобализације, који ствара тенденцију унификације, не изненађује чињеница да су се поново искристалисали апели за примену холистичког приступа као надасве инклузивног и свеобухватног, ${ }^{1}$ који, између осталог, подржава оно што би се могло назвати вишеструка дисциплинарност научних истраживања (као израз који премошћава нејединственост гледишта у погледу значења термина мултидисциплинарност, интердисциплинарност и трансдисциплинарност). ${ }^{2}$

Терминолошка „трвења” показала су неслагање у погледу хијерархије различитих видова вишеструке дисциплинарности. Научници су се сагласили да постоји комбиновање (мање или више интегративног карактера) садржаја из различитих области, али нису

\footnotetext{
${ }^{1}$ Ово је недавно апострофирано и у извештају Светског економског форума опаском да је од посебне важности „подучавати студенте да критички размишљају, те да кроз сарадњу са појединцима другачије вокације буду изложени разноликим гледиштима и идејама" (WEF, 2016).

${ }^{2}$ Ако су ниво и природа комбиновања већег броја дисциплина неодређени, користи се израз вишеструка дисциплинарност, који „покрива” мултидисциплинарност, интердисциплинарност и трансдисциплинарност (Lethtinen, 2013).
} 
били унисони у погледу прецизирања значења сваког од поменутих израза: који термин подразумева задржавање релативне самосталности дисциплина, који се односи на хармонизацију и формирање некакве синтезе гледишта потеклих из различитих дисциплина, нити какви су и колики трансформативни ефекти које разни облици сарадње продукују на сваку дисциплину понаособ (Petrisor, 2013).

Шире посматрано, оваква неслагања одражавају заступање једне од две потпуно супротстављене позиције: да су границе између дисциплина потпуно ирелевантне или да су оне од круцијалног значаја. Било је и аутора склоних веровању да је могуће истовремено заступати оба наведена виђења (Pforr, 2015). Заиста, са становишта садржаја - самог знања - границе између дисциплина нису важне, али добијају на значају уколико говоримо о односима моћи између дисциплина. Ако се задржимо на претпоставци да је искључиво реч о потрази за новим сазнањима, то би, на пример, значило безусловно прихватање сарадње међу дисциплинама унутар корпуса друштвених наука, будући да оне имају заједнички предмет проучавања (људско понашање).

Међутим, заступање става да су границе међу дисциплинама потпуно ирелевантне постаје проблематично уколико се упитамо да ли је „комбиновање” приступа који имају различито извориште имплицитно пожељна ствар? Не нужно, будући да је некад боље да постоје два паралелна приступа, а понекад се дешава да су исти некомпатибилни и/или контрадикторни (те је њихово комбиновање контрапродуктивно). А уколико трансфер идеја није двосмерног карактера, нити искључиво мотивисан сазнајним побудама, то умногоме мења однос снага међу дисциплинама и нужно намеће питање у чијем је интересу поменуто ширење граница неопходно.

Стога је циљ овог рада да, на основу увида у новију литературу, анализира корисност експанзионизма економске науке као једног од начина постизања вишеструке дисциплинарности. Реч је о теоријској анализи која износи аргументе којима се оправдава економски експанзионизам, начине његовог континуираног опстајања и консеквенце које је његово егзистирање досад изнедрило, или би могло произвести уколико се постојећи трендови наставе. То, између осталог, значи преиспитивање мотивације која лежи у основи економског експанзионизма, али и његове „продуктивности” посматране из угла напретка економске науке. Овакав приступ има приметно методолошко ограничење: будући да се корисност економског експанзионизма не може квантификовати, закључци којима се оцењује његов допринос представљају, заправо, нормативне процене. 


\section{ДА ЛИ СУ ГРАНИЦЕ ИЗМЕБУ ДИСЦИПЛИНА ИРЕЛЕВАНТНЕ?}

Питање „Да ли су границе између дисциплина ирелевантне?” предмет је дуготрајних филозофских и методолошких дискусија (Emmet, 2009), које су, као што смо већ напоменули, резултирале постојањем два екстремна гледишта: једног које тврди да постоји непроменљива граница (којом су омеђени подручје и методи анализе), те другог, широко прихваћеног, које сматра да је „прекрајање” граница могуће и пожељно. ${ }^{3}$

Уопштено говорећи, свако подручје анализе покрива мноштво проблема који су променљивог карактера. Другим речима, ни његова величина, а још мање концептуални садржај нису предодређени, већ се временом мењају (Mäki, 2008). Промене се догађају као резултат унутрашњег реструктурирања, ${ }^{4}$ али и тзв. процеса комбиновања, односно стварања својеврсних ,алијанси” (Savoiu \& Dinu, 2015).

„Комбиновање” се сматра (у мањој или већој мери) синонимом за уједињење, придруживање, повезивање или интегрисање концепата који припадају различитим областима науке (Lehtinen, 2013). Сарадња међу дисциплинама се успоставља из више разлога: уколико постоји потреба да се осмисли нова теорија или нека врста општег приступа, кад постојећи приступи нису међусобно искључиви, већ су њихове врлине комплементарне, уколико се мане неког од постојећих приступа могу анулирати врлинама неког другог, када је комбиновање користан начин да се попуне празнине између различитих теорија (или теорије и праксе) и слично. Инфилтрирање у

\footnotetext{
${ }^{3}$ Аутори који тврде да су научне дисциплине особени дискурси које карактерише кохерентност теорија, концепата, метода и специфичост правила за тестирање хипотеза (Lyotard, 1984; Fuller, 1991; Bridges, 2006) сматрају да би сваки напор да се превазиђу дисциплиране поделе био бескористан јер је комбиновање идеја између некомпатибилних подручја непродуктивно. Присталице опречног виђења тврде да је искорачење ван дисциплинарних оквира не само изводљиво већ и корисно (Becker, 1976; Akerlof, 1983; Coleman, 1990; Granovetter \& Swedberg, 1992), иако не мора бити реципрочног карактера (Kalleberg, 1995). О другачијим угловима посматрања дебате о дисциплинарним „међама” (гледиштима која излазе из оквира филозофских дискусија) шире погледати у: Krishnan, 2009.

${ }^{4}$ Тако је, на пример, унутрашње реструктурирање у економији допринело уситњавању (сегментирању) предмета проучавања, образаца анализе и водило је подвајањима по принципу гранских економија (економика пољопривреде, индустрије, саобраћаја, туризма...), по степену агрегираности (микро, макро, регионална, национална, међународна економија) или по субординацији предмета у односу на друге дисциплине (екологија је генерисала еко-економику, наука о предузетништву подстакла је развој предузетничке економије). Унутрашње реструктурирање је, такође, подвојило супротстављена гледишта - школе економске мисли, оформивши линију разграничења између ортодоксије и хетеродоксиje (Savoiu \& Dinu, 2015).
} 
друге области представља, између осталог, израз уверења да би једна (помало неочекивана, понекад непланирана) примена теорије на неки нови феномен могла бити успешна, у смислу да би могла произвести трансформативне ефекте за једну дисциплину или више дисциплина (Davis, 2010).

Унутар корпуса друштвених наука, линија разграничења између економије и других дисциплина постаје наглашенија са појавом маргинализма, да би етаблирањем неокласичног концепта као доминантне парадигме она била јасно подвучена. Економисти су се усредсредили на рационално понашање појединаца и проучавање тржишних активности, док су нерационално понашање и нетржишне активности представљале предмет проучавања осталих дисциплина друштвених наука. Овакво стање углавном је кореспондирало месту које је економија заузимала у једној од најпознатијих таксономија научних дисциплина коју је сачинио психолог Биглан (Biglan, 1975).

Обухвативши разлике међу дисциплинама по основу три кључна критеријума: Куновог поимања парадигме (које науке дели на тврде, парадигматске, односно природне и меке, непарадигматске, односно друштвене); степена применљивости (којим се прави разлика између чистих, примарно теоријских и примењених наука); имплицитног односа са живим и неживим системима, он је закључио следеће: економија (заједно са филозофијом и историјом) спада у тзв. непарадигматске (меке), чисто теоријске науке које „баратају” неживим системима, за разлику од пословне економије (финансија, рачуноводства, банкарства, маркетинга) која се сврстава у меке, али примењене дисциплине (Goel, 2010). ${ }^{5}$

У поменутој класификацији ваљано је перципирано оно што је раније етаблирано кроз унутрашње реструктурирање економије подвајање економије од пословне економије, а адекватно је и разврставање економије у тзв. non-life дисциплине будући да она заступа Робинсову дефиницију предмета истраживања као односа између циљева и оскудних средстава. Ипак, даљи развој догађаја у економској науци демантовао је Бигланову тврдњу да економија примењује холистички приступ у истраживању.

Временом је економску науку почело да карактерише спорадично, а данас далеко учесталије, прекорачење граница њеног подручја истраживања. Овај тренд се у литератури појављује под називом експанзионизам и претпоставља се да се исти може довести у ве-

\footnotetext{
${ }^{5}$ Подвајање пословне економије од чисте економије није неуобичајено. И код аутора који као критеријум узимају класификацију занимања, дисциплине бизниса спадају у предузетничке, док се економија сврстава у истраживачке (заједно са биологијом, социологијом, математиком, статистиком, физиком и сл.). Видети: Lattuca, Terenzini, Harper \& Yin, 2010.
} 
зу са реструктурирањем економске науке. Компликације које су настале „размимоилажењем” између ортодоксије и хетеродоксних гледишта тицале су се како језичке апаратуре тако и кључних закона и примењених метода, што отежава комуникацију међу супротстављеним „таборима” економиста. Отуда од свих друштвених наука (које садрже опонентне приступе), једино економију одликује постојање оштре линије разграничења између ортодоксног и хетеродоксних гледишта (Rotchild, 2008; Davis, 2007). Наиме, стандардна економска анализа искључиво се ослања на Робинсову дефиницију која, најблаже речено, економију своди на описивање екстерне реалности (између циљева и средстава). Сходно томе, ортодоксија испољава тежње да економија буде чиста наука, која се искључиво ослања на позитивистичке судове. Хетеродоксна становишта, с друге стране, сматрају да би економија требало да обезбеди адекватну анализу понашања појединаца, али и нормативну анализу како би друштво требало да изгледа (шта су пожељни исходи и како избећи оне непожељне), те су она наклоњенија нормативној (вредностима оптерећеној) науци. Схватање економске науке као позитивне је оно које доминира унутар дисциплине, а исто инсистира на коришћењу универзалних принципа који су лишени историјске или контекстуалне специфичности.

Кад су ортодоксни економисти дошли до закључка да је нелогично да универзални економски принципи имају ограничену примену, уследио је продор економске науке на „туђа” подручја анализе (Fine \& Milonakis, 2009). Економско теоретисање се, потом, умножавало кроз алијансе, најчешће конвергентног, али понекад и оне дивергентног типа (Savoiu \& Dinu, 2015). Овакви савези иницирани су предметом проучавања, коришћењем заједничких модела, те употребом истих методолошких поступака (од економске статистике до социоекономике).

А оно што се, са првим подухватима овакве врсте, сматрало неконвенционалном, те помало егзотичном економском анализом, временом је прерасло у устаљену навику коју су практиковали економски истраживачи који припадају доминантној парадигми (на тај начин доказујући да је континуирано „прекрајање” граница међу дисциплинама могуће и изводљиво).

\section{ВИДОВИ ЕКСПАНЗИОНИЗМА ЕКОНОМСКЕ НАУКЕ}

Искорачење ван традиционалних граница најчешће је мотивисано општим методолошким стандардом научног теоретисања - достизањем екпланаторне унификације, а то је уједно и почетни импулс за експанзионистичке аспирације које научне дисциплине исказују. Експанзионизам може попримити два облика: империјалистички (кад су нови феномени лоцирани на подручјима која традици- 
онално не припадају дотичној науци) и неимперијалистички (кад су нови феномени смештени на тзв. неокупиране територије). Будући да нам је намера да експанзионизам сагледамо кроз призму инволвирања економије и других дисциплина, задржаћемо се на проучавању првог од поменутих видова.

Сама метафора империјализма садржи неколико важних аспеката (Mäki, 2008). Поред оног који се дотиче положаја и угледа (престижа и моћи) дисциплине, у литератури се апострофирају империјализам метода (технике и стандарди истраживања) и империјализам подручја анализе (опсег феномена који се објашњавају).

Да ли експанзионизам економске науке покрива све поменуте аспекте? Да ли експанзионистичке тежње испољава економска наука у целини или само један њен део (доминантно гледиште у економији - тзв. mainstream)?

Проширење економске анализе на проучавање људског понашања у оним сегментима који припадају подручју других друштвених наука представља експанзионизам у форми империјализма подручја анализе. Тако је Бекер веровао да се економска рационалност може применити на све сфере друштвеног живота, Акерлоф је темељно проучавао социологију са намером да њена сазнања употреби у анализи економских феномена, а Колеман је покушавао да трансформише (и реконструише) социологију помоћу теорије рационалног избора (Fine, 2000). На овај начин се, међутим, не исцрпљују аспирације економије.

Наиме, поменуто ширење практично се изражава кроз конзистентну примену оруђа микроекономске анализе на проучавање нетржишних активности људи (образовање, наука, култура, здравство, дискриминација, породица, криминал, брак). У суштини, реч је о такозваном старом економском империјализму, који је, заправо, методолошки империјализам доминантне парадигме у економији (или тзв. империјализам метода). Он се не ослања на изналажење нових оруђа (метода) економске анализе, већ користи конвенционална, економији добро позната оруђа за проучавање феномена који су непознаница за економисте. Парадокс је тим већи, будући да се експанаторни принципи сужавају (од друштвених на индивидуалне), док се истовремено потенцијални опсег њихове примене шири (Fine, 2000; Ellison, 2014).

Чак је и Бекер (као утемељивач и перјаница економског империјализма) наглашавао да је разлика економије и других друштвених наука управо питање приступа, а не феномена који се проучавају (Becker, 1976). Кључни аргумент којим се оправдава ваљаност и подобност економског приступа савршено се уклапа у Дарвиновски приступ природне селекције: ако економски рационално понашање гарантује опстанак, онда је оно супериорније од других. 
Убедивши научну заједницу у области друштвених наука да је њена апаратура једина погодна за објашњавање раније неразјашњених феномена, ортодоксна економија наметнула је рационални избор као погодан за све активности, а не искључиво за оне тржишне, те отворила пут за материјализовање својих империјалистичких тежњи. Другачији приступи (ван економије или унутар ње) по правилу су сматрани неадекватним или погрешним јер се не уклапају у економско резоновање. Тако су, на пример, алтернативна (хетеродоксна) гледишта, која су обухватала мноштво различитих приступа који нису успели да се усагласе и да формирају ваљану опозицију ортодоксији, остала на периферији - изолована од доминантне парадигме, те се може говорити о некој врсти интерне колонизације у оквирима економске науке.

Дакле, ширење економије одвија се на више „фронтова” (подручја анализе, метода...), а чињеница да дисциплина успева да у тој мери искорачи из својих оквира представља показатељ њене успешности. Фактички се примена неокласичног приступа на нове феномене третира као подухват који продукује напредак економије, али и покушај да се докаже њен лидерски статус, тј. својеврсна надмоћност, у односу на друге дисциплине (што је показатељ империјализма положаја и угледа).

Посматрајући начин на који је еволуирао експанзионизам економске науке, с правом би се метафорички могло тврдити да је исти доживео својеврсну реинкарнацију кад је тзв. стари економски империјализам замењен новом формом. У чему су разлике између ова два облика империјалистичког економског експанзионизма? Стари економски империјализам је своје тежње остваривао на прилично агресиван, али транспарентан, начин (у литератури се то чак назива атаком киборга). ${ }^{6}$ Репрезентативни агент, или тзв. homo economicus, неокласичне економске анализе представља оличење киборга. И сама неокласика је таква: употребом технички савршеније апаратуpe, она покушава да обликује друштвене односе и да друштвену стварност уобличи не би ли иста одговарала моделима из стандардних уџбеника економије (Stilwell, 2012).

Нови економски империјализам далеко је софистициранијег карактера. Он се шири на суптилнији, а за друге друштвене науке пријемчивији начин. Унутар mainstream економије постала је приметна хетерогеност у проучавањима, која је делимично настала као резултат уподобљавања садржаја и/или метода из других дисциплина које не припадају искључиво корпусу друштвених наука. Стога

\footnotetext{
${ }^{6}$ Елисон је поменуту метафору преузео од Мировског. Киборг је, заправо, створење направљено од органских и синтетичких делова, лишено емпатије, али и слободне воље (Ellison, 2014; Mirowski, 2002).
} 
неки аутори (Davis, 2008; Davis, 2010; Collander, 2004) тврде да, захваљујући сарадњи са другима, економија није више монолитан систем, већ скуп хетерогених и релативно независних истраживачких програма. У суштини, поред програма који одавно егзистирају у економији (ортодоксног - неокласичног, али и традиционално хетеродоксних - у које спадају, на пример, посткејнзијанци, неорикардијанци, радикална политичка економија и слично), постоје и новији истраживачки програми (попут бихевиоралне економије, еволуционистичке економије, теорије игара) настали на основу интензивиране сарадње са другим научним дисциплинама - психологијом, биологијом, математиком, који спадају у тзв. mainstream хетеродоксију. ${ }^{7}$

Једино што је заједничко овим новим програмима и традиционалној хетеродоксији јесте чињеница да се заснивају на претпоставкама које су различите од неокласичних. По свим другим параметрима - одакле потичу, чињеници да припадају mainstream-y (нису на периферији), да се залажу за постојање једног доминантног приступа у економији - они су дијаметрално супротни традиционалној хетеродоксији. ${ }^{8}$

Неки од програма који егзистирају другде преобликовани су да се уклопе у економску науку (попут теорије игара, а делимично и бихевиоралне економије), други су узроковани променом истраживачких стандарда у науци уопште (попут експерименталне економије). Поред поменутих, и промене у домену пословне економије на први поглед изгледају као очити примери подршке неком од видова вишеструке дисциплинарности, поготово кад се апострофирају следећи конкретни примери: маркетинг је позајмљивао концепте и теорије из психологије и социологије (Lehtinen, 2013); слично се догодило у теорији организације и теорији управљања, у којој је тек

\footnotetext{
${ }^{7}$ Еволуционистичка економија је хетероген теоријски ток, чијем су развоју дали допринос теоретичари веома разноврсних провенијенција, укључујући и оне који припадају традиционалној хетеродоксији. Ипак, њено инкорпорирање у окриље mainstream-а почиње појавом књиге Theory of learning in games (коју су написали Drew Fudenberg и David Levine). Приметивши да је теорији равнотеже неопходан чвршћи основ од оног који нуди објашњење рационалности, они су у еволуционистичкој економији препознали добар материјал за конструисање другачијих (еволуционистичких) темеља mainstream економије. О томе шире погледати: Friedman, 1999.

${ }^{8}$ Кинг није сагласан са тврдњама Дејвиса и Коландера да је и у оквирима mainstream-a приметно извесно фрагментирање, због којег он поприма елементе хетеродоксности. Економија је, по његовом мишљењу, јединствена међу друштвеним наукама јер има монолитну доминантну парадигму (тога нема у политичким наукама, социологији, социјалној антропологији, па чак ни у економији до после II светског рата), која је изразито непријатељски настројена према алтернативним приступима. Види: King, 2013.
} 
један од 14 кључних доприноса настао као резултат истраживача који по вокацији припада подручју пословне администрације (Oswick, Feleming \& Hanlon, 2011). Суштински, реч је или о допунама (корекцијама у заштитном омотачу) неокласичне теорије или о умножавању методолошких поступака анализе који исту ту теорију приближавају стварности. Сви други новитети који би могли значити задирање у основне методолошке постулате (тврдо језгро неокласичног програма) третирани су као ирелевантни за објашњења економског понашања (Davis, 2013).

Тако је, на пример, иновација у микроекономији њена способност да истражи друштвене структуре, институције и обичаје, иако и даље на основама методолошког индивидуализма. Неекономски феномени, попут поверења, реципроцитета, навика, представљени су као начин на који индивидуе одговарају на тржишне несавршености. Фактички, иако је друштвена компонента поново уведена у економску анализу, то је учињено тако да су историјски и друштвени феномени редуковани на поједностављена „средства” за превазилажење информационе асиметрије (Fine, 2000).

Чак ни бихевиорална економија са концептом ограничене рационалности није довела у питање погрешност неокласичног резоновања, већ је нагласила његову некомплетност, те неопходност да се исто допуни на такав начин који би „кориговао људско понашање у смеру потпуне рационалности" (Ellison, 2014). Она је, дакле, задржала теорију рационалног избора као „тврдо језгро” и допунила помоћне хипотезе модификујући моделе на начин да могу да „дозволе” извесна когнитивна ограничења и неконвенционалне преференце, што јој је у знатној мери олакшало комуникацију са mainstream-ом (Dow, 2013).

Значајнија реоријентација економске теорије ка практичним питањима (иницирана прохтевима стваралаца економске политике) омогућена је употребом квази-експерименталних метода у економији криминала, образовања и здравства, што је резултирало новим „прекрајањем" граница између дисциплина (Panhans \& Singleton, 2015).

Империјализам је, фактички, и даље присутан, али се одвија на другачији начин: стари империјализам са агресивном дисеминацијом неокласичне доктрине рационалности замењен је новим, суптилнијим обликом који сарадњу са другим дисциплинама користи како би њихова сазнања и истраживачке стандарде прилагодио и инкорпорирао у економску науку, у сврху консолидовања доминантне парадигме. 


\section{ОЦЕНА МОТИВА И ПОСЛЕДИЦА ЕКОНОМСКОГ ЕКСПАНЗИОНИЗМА}

Какве је све последице анализирано инфилтрирање економије у подручја анализе других дисциплина произвело? Коришћењем SWOT анализе могуће је апострофирати снаге, слабости, прилике и претње које су настале као резултат империјализма као особеног вида економског експанзионизма. Економија у целини, а посебно ортодоксија, имали су несумњиве користи од тога: проширен је спектар истраживачких питања (отварањем нових поља анализе), учвршћена је методолошка доминација владајуће парадигме, те потврђена научна изврсност економске науке. Прилике да mainstream и даље „профитира” чине се неисцрпним: економски империјализам му непрестано изналази разнолике начине да се консолидује - било путем колонизације других друштвених наука, или употребом све езотеричнијих економских модела (потеклих из природних наука). Стога је унутрашње реструктурирање, упркос видљивим манифестацијама проблема у многим његовим аспектима, потпуно скрајнуто питање. Самодовољност и охолост спречавају доминантну парадигму да региструје у којој мери је репутација економије у стварном животу пољуљана. Широм света пословне школе постају атрактивне, а на штету чисте економије, која се и даље држи модела, теорија и претпоставки недовољно усклађених са захтевима праксе (Sharma, 2014). Такође, унутар економске науке је све очитија институционална надмоћност mainstream-а наспрам мноштва хетеродоксних концепата који су потпуно маргинализовани упркос све израженијој неспособности доминантне парадигме да изађе на крај са макроекономским проблемима.

Чињеница је да је глобална економска криза уздрмала многе постулате макроекономије, посебно оне који се тичу регулисања финансијских тржишта и питања монетарне политике, чиме је постало јасно да у макроекономији не постоји основа за стварање неке нове синтезе (Solow, 2008). Упркос томе, mainstream и даље негира два фундаментална проблема повезана са феноменом хијерархијског редукционизма (King, 2013): прво, социјални, политички и економски елементи толико прожимају функционисање сваког система да је немогуће о својствима целине закључивати на основу (чак и потпуног) познавања свих њених саставних делова (у противном је то тзв. грешка композиције); друго, промене у друштвеном, политичком, културном и економском контексту утичу и на целину и на саставне делове (другим речима, постоји и „силазна” узрочност). ${ }^{9}$ Ако на то

\footnotetext{
${ }^{9}$ Велики број различитих врста узрочника утиче на економске феномене, а мења се и релативна важност тих узрочних фактора са протоком времена (Hausmann, 1992).
} 
додамо оглушавање о забринутост испољену кроз коментаре да је образовање економиста превише ускогрудо, због чега су лоше припремљени за суочавање са проблемима стварног света (Leape, 2012), или пренебрегавање учесталих апела за неким „новим еклектицизмом" у подучавању економије којим ће се већи нагласак дати мултидимензионим знањима (Coyle, 2012; Pomorina \& Lait, 2012), caсвим је јасно због чега се препоруке неких економиста да микроекономија настави да следи математичко-статистичку трајекторију, а да макроекономија буде трансформисана помоћу сазнања из етике, филозофије и политике - нису материјализовале (Fox, 2013).

Иако историјски токови потврђују да се после великих привредних циклуса догађало преиспитивање економске науке, које је, по правилу, резултирало притисцима да се изврши коренита промена у доминантној парадигми или да се утемељи нека нова ортодоксија, чини се да се то сад не дешава.

Мада узвратни империјализам других друштвених наука може представљати претњу, судећи по досадашњим трендовима, мало је вероватно да ће се то заиста и догодити. Далеко већи проблем може изазвати претерано „кокетирање” економске науке са математиком. Иако је оно економији несумњиво помогло да постигне већу егзактност и задобије посебан, супериорни, статус унутар корпуса друштвених наука, исто би је могло довести до тачке да постане тек субдисциплина унутар математике.

Експанзионизам се, у литератури из филозофије науке, у начелу правда тврдњом да је усмерен на специјални случај опште методолошке норме чије задовољење подразумева остваривање експланаторне унификације (Mäki, 2008). Његова неупитност, чак и у империјалистичкој форми, у економији се аргументује на другачији начин (Davis, 2015): ${ }^{10}$ a) експанзионизам се заснива на размени идеја по концепту компаративних предности, а не на њиховој принудној примени; б) флуктуација идеја је прави начин промовисања вишеструке дисциплинарности.

Да ли је експанзионизам економске науке оличење неког од наведених „идеала"? Судећи по начинима на које се испољавао, чини се да није. Концепт „слободне трговине” идејама у оквиру економског империјализма је, заправо, парадигматски пример идеолошког представљања теорије: она приказује однос међу наукама

\footnotetext{
${ }^{10}$ Фактички, теорија функционише симултано на неколико нивоа - као теорија трговине и као израз идеала интердисциплинарности. Дејвис (2015) прави разлику између интердисциплинарности, у чијој је основи релативна аутономија научних дисциплина које не могу трансформативно деловати једне на друге, насупрот потпуно опречног значења израза мултидисциплинарности.
} 
као сарадњу која се одвија на задовољство свих учесника, што је сасвим супротно од њених импликација.

Иако је сам развој економске науке текао у смеру повећаног преплитања међу дисциплинама, економија одбија да призна да јој је сарадња са оним наукама које третира као „корисне” или „супериорне" (попут биологије, односно физике) донела бројне новитете (Savoiu $\&$ Dinu, 2015) у виду креативне примене нових метода који јој помажу у разумевању, продубљивању и предвиђању економских феномена. Mainstream економија стално се опире таквим идејама, налазећи се у некој форми изолације (Davis, 2013). Једино што јој се чинило примереним је извоз економских концепата другде. Већина ортодоксних економиста, дакле, заступа став да друге науке не могу допринети објашњењу економског понашања. Приде, визија mainstream-a да је економија самостална (донекле затворена) наука је покушај додељивања особеног статуса истој, чиме се потенцира да се економски принципи могу генерализовати на сваки друштвени контекст. ${ }^{11}$

Одбрана економског империјализма темељи се на аргументацији да је реч о слободној „трговини идејама” (а не њиховом наметању), која, као и свака друга трговина, доноси добитке за све. Годинама уназад тврди ce (Lazear, 2000) да је компаративна предност економије њена способност да апстрахује (да буде аналитичнија и ригорознија од осталих друштвених наука), док се друге области истраживања могу похвалити да је „ширина промишљања” оно што их издваја. Заступање теорије компаративних предности подразумева, наравно, да је могућ и тзв. узвратни империјализам - у виду увоза туђих идеја у економију (што се, као што смо видели, заиста и дешава). Да би одбранила сопствену аутономију (од узвратног империјализма), mainstream економија стриктно се држала идеје о релативној самосталности наука уопште, која подразумева да исте не могу трансформативно деловати једне на друге.

Ова аргументација је, по мишљењу Дејвиса (Davis, 2015), шупља, јер аналогија (са стварним светом економије) налаже да, упркос реторици „слободне трговине”, науке могу империјалистички „инвестирати” (и поменутим „инвестирањем” продуковати трансформативне ефекте једних на друге). Самим тим се релативна аутономија учесника доводи у питање, те је ортодоксија била принуђена да експанзионизам економске науке брани једносмерном трансмисијом својих идеја, тј. наметањем праксе рационалног избора свуда.

Према томе, у околностима кад постоји могућност узвратног империјализма, теорија трговине идејама је у први мах функциони-

\footnotetext{
${ }^{11}$ Сузбијање свега што није уклопиво у логику mainstream-а Дејвис (2015) назива top-down концептом науке, насупрот bottom-up концепцији, која инсистира на сталној измени односа између доказа и теорије.
} 
сала као одбрамбена стратегија, да би потом „послужила” као офанзивна стратегија у одбрани неокласичне економије проширењем њеног домена под плаштом сарадње, при којој се задржава релативна аутономија научних дисциплина.

Ортодоксни економисти су, дакако, били свесни тога да је немогуће да науке не продукују међусобне утицаје. А опет, нису могли то да прихвате, не због могућег урушавања одбране економског империјализма, већ због чињенице да је неокласична теорија дубоко повезана са идејом о релативној аутономности путем њеног принципа да су економски агенти, заправо, атомистички субјекти са сопственим егзогено датим преференцијама - јер да су то усвојили, онда би (по аналогији) њихова кључна доктрина била изложена аргументима да су агенти међусобно повезани, те да је стандардна анализа оптимизације бесмислена.

Оваква (контрадикторна) ситуација навела је ортодоксију да осмисли тзв. перформативну стратегију (као ново ширење програма економског империјализма), која доказује да „свет представља одраз саме теорије" (Davis, 2015). У том смислу, задатак економије је да „открије” да између атомизираних учесника у другим дисциплинама постоје исти односи као у економији. Дакле, све што су неокласични економисти морали да ураде да би показали да пре описују него што прописују понашање - било је да „открију” да се људи у нетржишним околностима понашају рационално. ${ }^{12}$ Онда се за економију не би могло тврдити да је трансформисала друге науке путем активног промовисања сопственог програма, идеал помињане интердисциплинарности (заправо релативне самосталности) био би осигуран, а површно посматрано би се чинило да нема основа за идеју да економски империјализам укључује „доказивање надмоћности”.

Проблем са наведеном аргументацијом је у томе што иста заборавља да су у комплексном свету науке и њихови односи стално променљива ствар. Стога се науке могу сматрати релативно аутономним само на кратак рок. А интеракције међу дисциплинама се не би тако звале уколико би се искључиво сводиле на једносмерни ток идеја.

\footnotetext{
12 То је бар делом укључивало реинтерпретацију и незнатно проширење (помало нејасног) концепта подстицаја и обликовање окружења у којем се чине избори. Поента је у следећем: кад је окружење обликовано на неокласичан начин, онда постаје могуће „открити” да људи управо имају оне подстицаје за које је то окружење конструисано! Скорија манифестација ове логике је теорија дизајнирања механизма (за коју је 2007. додељена Нобелова награда за економију), а која, по мишљењу Дејвиса, представља оличење перформативног неокласичног програма (Davis, 2015).
} 
Империјализам економије се ни из угла филозофије наука није показао сврсисходним. Наиме, будући да теорија коју mainstream економија нуди другима има епистемолошка ограничења, експанзионистичке тежње нису резултирале (тако жељеном) експланаторном унификацијом (Mäki, 2008).

Mainstream економија је, у суштини, помоћу ваљано прокламованих механизама покушала да оствари вешто замаскиран циљ да се афирмише као универзална наука. Званично је подржавала вишеструку дисциплинарност као идеал, чврсто заступајући став о слободном протоку идеја и њиховој размени по концепту компаративних предности. На папиру се декларисала као промотер конкуренције и ривалства међу програмима, а у пракси је то негирала маргинализацијом хетеродоксних гледишта унутар дисциплине, а на нивоу међудисциплинарне сарадње покушајем наметања сопственог приступа као опште филозофије друштва.

\section{ЗАКЉУЧАК}

Стремљења ка неком од облика вишеструке дисциплинарности (мултидисциплинарности, интердисциплинарности или трансдисциплинарности) обично настају као резултат убеђења да традиционалне дисциплине не успевају или нису вољне да се позабаве неким важним питањима. У литератури влада подељено мишљење о потенцијалним користима које реализација поменутих тежњи може произвести: неки их сматрају леком за штетне ефекте претеране фрагментације, други их третирају као покушај ширења видика и потпунијег сагледавања било ког истраживачког питања. Опонентни ставови указују на дубље несугласице које се јављају по питању циља који би требало остварити уз помоћ концепта вишеструке дисциплинарности: да ли је у питању (како филозофи претендују да буде) конципирање јединствене (унифициране) теорије знања или стимулисање конкуренције алтернативних приступа истој теми.

Mainstream економске науке је, најблаже речено, погрешно интерпретирао, а можда и злоупотребио, концепте мултидисциплинарности и интердисциплинарности: инсистирањем на релативној аутономности наука (држећи се тврдњи о одсуству било каквих трансформативних ефеката између њих) онемогућавао је и сузбијао трансфер оних идеја које нису уклопиве у неокласичну теорију. Истовремено је форсирао њено несметано ширење на нетржишне домене анализе, са циљем да је етаблира као општу теорију - примењиву на људско понашање у свим областима друштва.

Овакво понашање доминантне парадигме економске науке нарушава принципе плуралности, мења статус неких дисциплина унутар корпуса друштвених наука, а на нивоу научног теоретисања 
угрожава будуће прилике за неке од видова вишеструке дисциплинарности. Експанзионизам економске науке је (у својој најочитијој империјалистичкој форми), продукујући поменуте негативне консеквенце, створио „страх”, али и отпор научне заједнице према (не)оправданом ширењу и прекрајању дисциплинарних граница, што може знатно отежавати даље иницирање интердисциплинарне или мултидисциплинарне сарадње, а у најгорем случају обесмислити и саму идеју вишеструке дисциплинарности.

\section{ЛИТЕРАТУРА}

Akerlof, G. (1983), Loyalty Filters. American Economie Review, 73(1), 54-63.

Becker, G.S. (1976). The economic approach to human behavior. Chicago: Chicago University Press.

Biglan, A. (1975). The characteristics of subject matter in different academic areas. Journal of Applied Psychology, 57(3), 195-203

Bridges, D. (2006). The Disciplines and the Discipline of Educational Research, Journal of Philosophy of Education, 40 (2), 259-272

Collander, D., Holt, R. \& Rosser, J. (2004). The changing face of mainstream economics, Review of Political Economy, 16(4), 485-499.

Coleman, J. (1990). Foundations of Social Theory. Harvard University Press.

Coyle, D. (2012). Economics education after the crisis: are graduate students fit for purpose? Retrieved from: http://www.res.org.uk/view/article5apr12 Correspondence.html

Davis, J. (2015). Economics imperialism versus multidisciplinarity, 2015 STOREP Conference Plenary Lecture, Retrieved from: http://www.johnbryandavis.net/ uploads/2/2/7/3/22734340/econ_imperialism.pdf

Davis, J. (2013). Economics, Neuroeconomics, and the Problem of Identity, Retrieved from: http://epublications.marquette.edu/econ_workingpapers/53

Davis, J. (2010). Mäki on economics imperialism. Retrieved from http://epublications. marquette.edu/cgi/viewcontent.cgi?article=1003\&context=econ_workingpapers

Davis, J. (2008). The turn in recent economics and the return of orthodoxy. Cambridge Journal of Economics, 32(3), 349-366.

Davis, J. (2007). The turn in recent economics and return of orthodoxy. Retrieved from http://ssrn.com/abstract=1004064

Dow, S. (2013). Formalism, rationality and evidence: the case of behavioural economics, In: Special issue in honour of Mark Blaug, Erasmus Journal for Philosophy and Economics, 6(3), 26-43.

Ellison, S. (2014). Attack of the cyborgs: Economic imperialism and the human deficit in educational policy-making \& research. Journal of Educational Controversy, 8(1), $1-15$.

Emmett, R.B. (2009). History of economics and history of science: A comparative look at recent work in both fields. Retrieved from https://www.academia.edu/1108264/ History_of_economics_and_history_of_science_A_comparative_look_at_recent_ work_in_both_fields.

Fine, B. (2000). Economics imperialism and intellectual progress: The present as history of economic thought? History of Economics Review, 32(1), 10-36.

Fine, B. \& Milonakis, D. (2009). From economics imperialism to freakonomics: The shifting boundaries between economics and other social sciences. New York: Routledge. 
Fox, J. (2013). The end of economists imperialism. Retrieved from: https://hbr.org/2013/ 01/the-end-of-economists-imper.html.

Friedman, D. (1999), Evolutionary Economics Goes Mainstream: A Review of The Theory of Learning in Games. Retrieved from: http://citeseerx.ist.psu.edu/ viewdoc/download?doi=10.1.1.399.2801\&rep=rep1\&type=pdf

Fuller S. (1991), Disciplinary boundaries and the rhetoric of the social sciences. Poetics Today, 12(2), 301-325.

Goel, S. (2010). Well rounded curriculum - an insight from Biglan's classification of disciplines, Retrieved from: https://goelsan.wordpress.com/2010/07/27/biglansclassification-of-disciplines/

Granovetter, M. \& Swedberg, R. (eds.). (1992). The Sociology of Economic Life. Westview Press.

Hausmann, D. (1992). The limits of economic science, In: Hausman, D. (ed.), Essays on Philosophy and Economic Methodology, (pp. 99-105), Cambridge: Cambridge University Press.

Kalleberg, A. (1995). Sociology and Economics: Crossing the Boundaries, Social Forces, 73(4), 1207-1218

King, J. (2013). A case for pluralism in economics, The Economic and Labour Relations Review, 24(1), 17-31.

Krishnan, A. (2009). What are Academic Disciplines, Some Observations on the Disciplinarity vs Interdisciplinarity debate, Retrieved from: http://eprints.ncrm.ac. uk/783/1/what_are_academic_disciplines.pdf

Lattuca, L., Terenzini, P., Harper, B.J. \& Yin, A. (2010), Academic environments in detail: Holland's theory at the sub-discipline level, Research in Higher Education, 51(1), 21-39.

Lazear, E. (2000). Economic imperialism. Quarterly Journal of Economics, 115(1), 99-146.

Leape, J. (2012). Good economists need more than economics: multidisciplinary LSE 100 course". In: Coyle, D. (ed.) What's the use of economics? Teaching the dismal science after the crisis. (pp. 183-192). London, UK: London Publishing Partnership.

Lehtinen, U. (2013). Multidisciplinarity in theory building: possibilities of combining, Retrieved from: http://eujournal.org/index.php/esj/article/viewFile/1225/1234

Lyotard, J. M. (1984). The Postmodern Condition, A Report on Knowledge, Manchester: Manchester University Press

Mäki, U. (2008). Economics imperialism: Concept and constraints. Retrieved from http://www.helsinki.fi/tint/maki/materials/ImpCCproofs3.pdf.

Mirowski, P. (2002). Machine dream: Economics becomes a cyborg science. New York: Cambridge University Press.

Oswick, C. Feleming, P. \& Hanlon, G. (2011). From Borrowing to Blending: Rethinking the Processes of Organizational Theory Building, Academy of Management Review, 36(2), 318 - 337

Panhans, M.T. \& J.D. Singleton, J.D. (2015). The empirical economist's toolkit: From models to methods. CHOPE Working Paper No. 2015-03, Center for the History of Political Economy, Duke University. Retrieved from http://hope.econ.duke. edu/node/1126.

Petrisor, A.I. (2013). Multi-, trans- and inter-disciplinarity, essential conditions for the sustainable development of human habitat, Retrieved from: http://uac.incd.ro/ Art/v4n2a06.pdf

Pforr, T. (2015). Meaning construction and the socialisation of economic ideas: an autobiographical approach. $\mathrm{PhD}$ thesis, University of Warwick. 
Pomorina, I. \& Lait, A. (2012), What post-crisis changes does the economics discipline need? Retrieved from: http://www.res.org.uk/view/article5apr12 Correspondence.html

Rothschild, K.W. (2008). Economic imperialism. Retrieved from http://www.analyseund-kritik.net/2008-2/AK_Rothschild_2008.pdf

Savoiu, G. \& V. Dinu, (2015). Economic Paradoxism and Meson Economics, Amfiteatru Economic, 17(39), 776-798.

Savoiu, G. (2014). The impact of inter -, trans - and multidisciplinarity on modern taxonomy of sciences, Current Science, 106(5), $685-690$.

Sharma, S.K. (2014), Multi-disciplinarity of sciences, current economics and business, International Journal of Multidisciplinarity in Business and Science, $1(1), 1-5$.

Solow, R. M. (2008). The state of macroeconomics, Journal of Economic Perspectives, 22(1), 243-246.

Stilwell, F. (2012). Teaching political economy: Making a difference? Retrieved from http://spe.library.utoronto.ca/index.php/spe/article/view/18578/15509

WEF (2016), Global Competitiveness Report 2016-2017.

\title{
EVALUATION OF ECONOMIC EXPANSIONISM THROUGH THE PRISM OF MULTIPLE DISCIPLINARITY
}

\author{
Slavica Manić \\ University of Belgrade, Faculty of Economics, Belgrade, Serbia
}

\section{Summary}

Generally speaking, each area of analysis covers a multitude of problems that are changeable (neither its size not to mention its essence is predetermined). Changes occur either as a result of internal restructuring, or as a product of the so-called combining and creating a kind of "alliances". The scientists agreed that combining the contents from different areas, and therefore the rewriting of boundaries between disciplines, may cause positive consequences, if it is being motivated exclusively by the matter of knowledge. However, it becomes questionable when the transfer of ideas is not bidirectional, nor of the same intensity, since it can violate the balance of power between disciplines. This paper evaluates the expansionism of economic science through the prism of multiple disciplinarity, in order to determine whether the interfering of the economics with other science's affairs is predominantly positive or negative.

Basing on a theoretical analysis that relies on insights into the latest literature, we presented arguments that justify economic expansionism, the ways of its continuing revival as well as the consequences that its existence has so far produced or could produce if actual trends continue to exist.

The expansionism of economic science turns to be imperial by nature since it includes every known meaning of imperialism: the imperialism of research field (economics deals with non-market phenomena that traditionally belong to other sciences), imperialism of methods (economic science uses neoclassical methods of analysis) and the imperialism of reputation (imposing its own approach economics tried to become a universal science, i.e. the one that is superior to other disciplines of social sciences).

As a result, the economic science generally, and orhodoxy particularly have undoubted benefits from it: the range of research questions was expanded (by opening new fields of 
analysis), the methodological dominance of neoclassical approach was strengthened, and the excellence of the very discipline is confirmed. Opportunities for the mainstream to continue to "make a profit" in this regard seem inexhaustible: economics imperialism constantly identifies various ways to consolidate dominant paradigm - either through the colonization of other social sciences, or by the increasing use of diverse models (derived from natural sciences). The inevitability of economic expansionism is justified by the following arguments: it is an exchange of ideas according to the concept of comparative advantages; the fluctuation of ideas is the right way to promote multiple disciplinarity.

Our analysis proved that the mainstream economics at least misinterpreted, and perhaps abused, concepts of multi and interdisciplinarity: by insisting on relative autonomy of sciences (supporting the absence of any transformative effects between them) it prevented and suppressed transfer of those ideas that are not fitting into neoclassical theory. At the same time it insisted on the smooth expansion of neoclassical approach to other's domains of analysis, with the aim to establish it as a theory applicable to studying human behavior in all areas of life.

Such a behavior of the dominant paradigm in economic science actually prevents competition and rivalty between different approaches, undermines the principles of pluralism and changes the status of certain disciplines within the social sciences in favour of economics. It also jeopardizes future opportunities for some form of multi-disciplinarity in the scientific theorizing. Producing the aforementioned negative consequences, expansionism of economic science (in its most obvious - imperialist form) created "fear", but also the resistance of the scientific community to almost any kind of expansion and redrawing of disciplinary boundaries (no matter whether it is justified), which can significantly impede the further initiation of inter and multidisciplinary cooperation, whereas in the worst it can make the idea of multiple disciplinarity pointless. 